$$
\begin{aligned}
& \text { SF } 239 \\
& . A 48
\end{aligned}
$$





\section{DIFFERENCES}

\section{DAIRY PRODUCTS.}

BY

HENRY E. ALVORD.

FOR GENERAL DISTRIBUTION

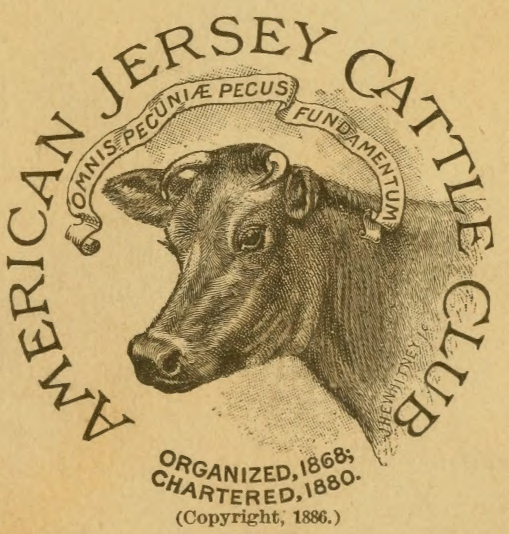

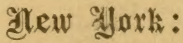

PUBLISHED BY THE CLUB BY PERMISSION OF THE AUTHOR.

$$
\text { JuLY, } 1888 .
$$





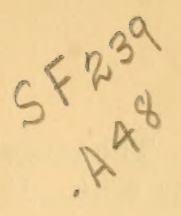

\title{
DIFFERENCES IN DAIRY PRODUCTS.
}

\author{
BY HENRY E. ALVORD.
}

Milk is a fluid, and has been so regarded from time immemorial. It has been bought and sold by liquid measure. And in referring to the use of milk it is ordinarily spoken of as a fluid. We say commonly that we drink milk, and rarely speak of eating it. Yet milk is food rather than drink. It is the perfect food provided by Nature for the young of the most important grand division of the animal kingdom. And we know it is largely consumed as food by human beings of all ages. It is, then, as a food, that milk, and chiefly the milk of the cow, is so conspicuous in commerce and in domestic economy. But our first idea of human food is a solid substance; and although some food appears in a liquid form, it is valued for the solid matter it contains. Milk is no exception. It is a fluid because largely composed of water; but all its other constituent parts are solids, and they are what give milk its food value. Some of these constituents, the curd or caseine, the sugar and the salts or mineral matter, are dissolved in water ; other parts, the fats, are in semi-solid particles, held in suspension in the fluid, causing the opaque appearance. So milk is at once a solution and an emulsion. (By "emulsion," a word itself meaning milk-like, we intend to describe a physical mixture of different substances like oil and water, which do not form a chemical union.) To thoroughly understand milk, its composition and value, it must, therefore, be examined chemically and physically.

Chemical examination reveals the fact that milk varies greatly in its composition, or, rather, in the relative quantity of its parts. By carefully evaporating the water we secure all the other parts, and these collectively are called the "total solids" of the milk. The fat may then be easily separated from the rest and its quantity determined, the remainder being what are known as "the solids not fat." These, in turn, are usually separated into caseine, sugar and salt, or ash. The notable differences in milk are in the proportion of fat 
to other solids, and of the total solids to the water. The range of total solids is from below 11 per cent. to above 20 per cent. It is unusual, however, to find pure milk from a healthy cow with much less than 12 per cent. solids, and over 16 per cent. is also uncommon. The highest record found for a single cow is 23.43 per cent., and the lowest, 10.55 per cent., the former a Jersey and the latter a Holstein ; and the highest for a herd, for any length of time, is 15.45 per cent., for a herd of registered Jerseys in the State of New Jersey, tested for one full year, and the lowest, $11.7 \%$ per cent., for forty-five Dutch cattle at Proskau, for over two years, as reported by Dr. Schmoeger in the "Milch Zeitung," for 1881. The range of fat is even greater, proportionally, being from 2 per cent., or even less, to 12 per cent. But 3 per cent. is as low as allowable for pure milk from a well kept cow, and anything over 6 per cent., maintained for any length of time, is very rare. The fats of milk being included in the solids and the most variable portion, we naturally find most fat with the most solids, and the lowest fat with the lowest total solids, and vice versa. The highest and lowest records of fat which I have seen for single cows are 12.53 and $2 . \% 0$ per cent., being the same animals previously referred to as showing the extreme for total solids. Both were examined at the New York Agricultural Experiment Station. The highest and the lowest for a herd, 5.53 and 2.82 per cent., respectively, for Jerseys and Holsteins.

Physical examination, chiefly with a microscope, shows the condition in which the fat is held in the serum or fluid, and demonstrates great differences, in this particular, in the milk of different cows. The fat is found in globular form, myriads of these minute globules floating at will, in the otherwise colorless fluid, and giving to milk a physical character and quality quite distinct from its chemical quality. The main differences in these fat globules are in their average size and their uniformity of size as seen in different milks. It requires from 1,500 to 10,000 of these fat globules, placed side by side, to cover an inch in length; from 6,000 to \%,000 is a fair average. Sometimes, but not often, globules are found as large as 1-1000th of an inch in diameter, and in most milk there are those so minute as to be called granules, to distinguish them, and which are 1-25000th of an inch, or less, in diameter. Dr. Sturtevant, as the result of thousands of examinations, reported the average size of the fat globule in Jersey milk as 1-5252d of an inch, and in Ayrshire milk 1-7080th of an inch; the average size for Dutch or Holstein milk was still smaller. The larger the fat globules in any milk, the easier and quicker they separate from the fluid, and the more difficult it is 
to remix the parts; that is, the cream and the skim milk. I quote from Dr. Sturtevant on this subject of the differences in milk as regards its physical character: "The globule of the milk of the Jersey breed is larger than that of other breeds examined, and there are fewer granulez; as a result, the cream rises with considerable rapidity, and so completely as to leave a very blue skim milk, which does not readily remix with the cream. The milk of the Ayrshire breed furnishes a globule intermediate in size between the Jersey and the Dutch, and a predominant feature is the presence of numerous granules, or extremely small globules, which give a white rather than a blue appearance to the skim milk. Of the three breeds we are considering, the Dutch or American-Holstein presents the smallest globule to its milk. The globules are more uniform in their size than in the Ayrshire milk, and there are fewer granules. The cream, on account of the uniformity of size of the globules, rises completely making the skim milk appear blue, and on account of their small size, the cream can be readily mixed with the skim milk by shaking." Prof. Arnold adds, on this point: "The milk of Devons closely resembles that of Jerseys ; the milk of native cows is usually similar to that of Ayrshires, and the milk of Shorthorn cows somewhat resembles that of the Dutch, but the globules are larger and not so uniform in size and quality."

Investigations in another direction have determined what may be called either physiological or hygienic differences in milk. The character of the solids, and particularly of the fats and caseine, appears to differ as regards digestibility. It is believed by some that the caseine is more or less in a solid form, instead of all dissolved, and that this solid portion varies greatly in different milks. This variation makes one milk much more wholesome, or easier of digestion, than another, which becomes a matter of importance in the case of infants and invalids. Furthermore, milk differs in the matter of color. Some cows, as a part of their animal economy, have the power of secreting, in various parts of the body, an orange-colored pigment. This coloring matter has a special affinity for the fatty tissues, and appears in the fats of the milk. In this respect, as stated, cows differ greatly, and the matter of color seems to have no relation whatever to the quantity or other qualities of milk. It is certain that color is in no respect an indication of the quantity of fat in a milk, or of the butter that milk will produce. Erroneous views on this point have led to undue value being placed on high-colored milk and cows producing such. Repeated trials have shown that cows whose bodies and milk are destitute of this often-prized quality yield 
milk richer in the quantity and quality of butter produced from it than other cows specially selected for their high development of this peculiar attribute of color.

Although the variations in milk, as described, appear more or less. among cows of the same breed, and more decidedly among animals of mixed blood, it has been well established that the contrast is most marked between pure-bred cows of the several recognized dairy breeds of cattle. The differences in the milk from these breeds is so positive as to be regarded as characteristic of the breeds themselves. Thus, high medical authority pronounces the Ayrshire milk to have special hygienic properties which adapt it, above all others, to the use of infants and invalids. The predominating feature of Guernsey milk is the deep orange color which becomes imparted to the butter. The cattle of Holland and Holstein are noted for yielding enormous quantities of milk, very low in fat and other solids, but of such physical character as to make it the best of all to transport long distances and maintain an even quality for retail city delivery. And the Channel Island cattle-the Guernseys and Jerseys-give the highest per cent. of fat and total solids, together with high color. The differences which are to be found in milk and the products of milk are, then, mainly a difference of breeds. The study of the characteristics: of the milk of different breeds of cattle has, therefore, a direct practical bearing, and becomes of interest to all consumers who are discriminating buyers, and to all producers whose business sense leads them to take every advantage of a discriminating market. Heretofore there has been difficulty in pursuing this study because of the lack of sufficient data. In the old records, of which there is a great. mass, we have widely varying results from the examination of milk, cheese and butter; but they are valueless as bearing on the question of breed, because rarely, if ever, do such records give any history of the origin of the substances examined. Facts of a more complete and satisfactory character have been accumulating of late years, however, and while it is not unlikely that further data will cause some modification of existing averages, and the deductions to be made from them, we have now enough to at least make a very interesting subject for study and to lead to some well-defined conclusions.

My attention has been attracted, for two or three years, by the discussions of human foods, and the different ways of comparing them. I have been specially interested in noting the high position occupied by dairy products as economical articles of food. And this paper was suggested by, and is mainly based upon, certain tables, with their explanations, which are to be found in the proceedings of recent. 
meetings of the American Association for the Advancement of Science. Those relating to the differences of milk-or rather the variation in the food value of different milks, and comparing dairy products in this respect with other articles of food-were presented in the Economic Section of the Association, and the one on variations in butter was presented in the Chemical Section, and also contributed to the last meeting of the Society for Promoting Agricultural Science, and published in its proceedings for 188\%. With such indorsement, we may rely upon the accuracy and value of these data, and may deduct some important facts from their consideration.

The tables to which attention is first invited were prepared two years ago, in connection with a discussion of "the food question," to illustrate the "Relative Values of Human Foods," upon the basis of their chemical composition. They have been amplified and rearranged within the past year, separating the long list of dairy products from the other foods, and giving a new title suited to my present use of them. (Table illustrating the Differences in Dairy Products, and comparing the latter with various other standard foods.) The figures, as presented to the American Association, remain unchanged, and they represent a very large number of authentic analyses. In relation to every article named, the composition on which its value is based is the average of all the analyses of like articles of undoubted history which could be found recorded, upon reliable authority, up to the first of July, $188 \%$.

'There are different ways of comparing human foods upon the score of economy. If one attempts to consider at once their digestibility, chemical composition and usual cost, besides other conditions which should not be ignored-nervine properties, for example-the problem becomes very complex. It is hard to define the average human stomach, and we are so much in the dark on the questions of actual digestion and assimilation of different forms of food that it is safer to drop that factor than to include it. At all events it is better to approach the subject by stages; and in this instance we consider, in combination, the chemical knowledge of foods and their market prices. The basis of comparison is all important. The necessity is apparent of separating foods into two grand divisions, animal and vegetable, and of selecting a basis for each. It is needless to here fully explain the manner in which these tables were prepared. For the details, reference is made to the original form of publication. (Vol. xxxiv., Amer. Assoc. Advancement of Science, 1885, page 504.) The statement is sufficient, now, that pure lard, at 12 cents per pound, and average ox beef, flesh free from the bone, at 16 cents per pound, 
taken as the basis, gives the average cost of the nutrients in animal foods as 72 cents per pound for protein, 12 cents for fats, and $\%$ cents for carbo-hydrates. This assumes the proper ratio between fats and carbo-hydrates to be 1.75 to 1 ; so that to combine these two, the quantity or per cent. of fat in any analyses is multiplied by 1.75 and added to the carbo-hydrates. For vegetable foods, the potato, at 60 cents per bushel, or 1 cent a pound, is the basis, and the value of vegetable protein thus fixed at 10 cents per pound, and of carbo-hydrates at 4 cents per pound.

Based upon these values, the following tables have been compiled. They give the chief nutrients, the computed value, and the average price, approximately, of 100 pounds of about thirty different dairy products, and, for comparison, an equal number of other common articles of food, one-third animal and the rest vegetable. A column is added at the right of each table, indicating by the signs plus $(+)$ and minus (-), whether the usual selling price, as stated, is more or less than the computed food value. 
Titble Illustrating the Differences in Dairy Products, and Compuring the Latter with various other Standard Food Products.

\begin{tabular}{|c|c|c|c|c|c|}
\hline 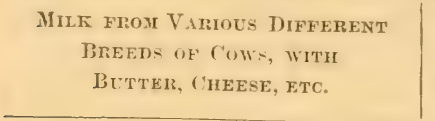 & $\begin{array}{l}\text { Pounds } \\
\text { Protein } \\
\text { in } 100 \\
\text { pounds. }\end{array}$ & $\begin{array}{l}\text { Pounds } \\
\text { Carbo- } \\
\text { hydrates } \\
\text { in } 100 \\
\text { pounds. }\end{array}$ & $\mid \begin{array}{c}\text { Compnted } \\
\text { Vulue per } \\
100 \text { pounds. }\end{array}$ & $\begin{array}{l}\text { Average } \\
\text { Markit. } \\
\text { Price per } \\
100 \text { pounds. }\end{array}$ & $\begin{array}{l}\text { Price, } \\
\text { Greater or } \\
\text { Less than } \\
\text { Value. }\end{array}$ \\
\hline 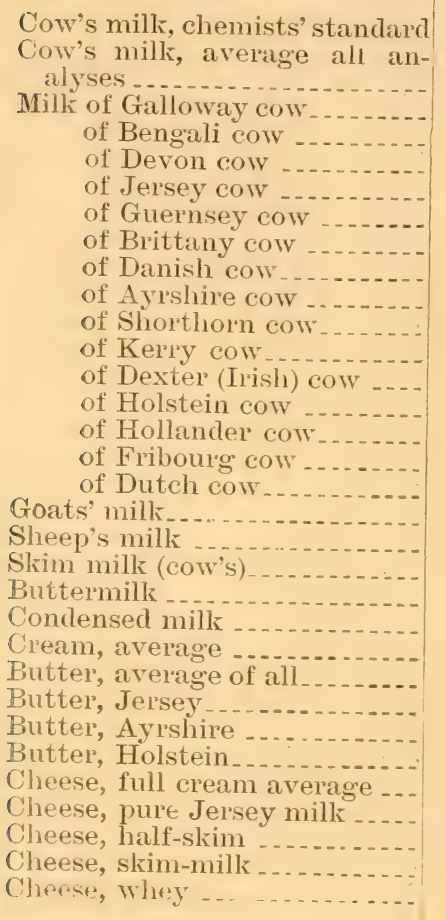 & $\begin{array}{r}3.41 \\
5.36 \\
5.19 \\
4.37 \\
3.98 \\
3.97 \\
3.96 \\
3.90 \\
3.76 \\
3.74 \\
3.40 \\
3.35 \\
3.15 \\
3.03 \\
2.84 \\
2.78 \\
3.80 \\
7.12 \\
3.06 \\
3.78 \\
16.07 \\
3.70 \\
0.86 \\
1.30 \\
1.40 \\
2.65 \\
27.16 \\
28.18 \\
27.62 \\
32.65 \\
8.65\end{array}$ & $\begin{array}{r}11.23 \\
8.86 \\
10.07 \\
12.56 \\
13.88 \\
13.63 \\
10.89 \\
10.69 \\
11.65 \\
11.83 \\
10.96 \\
11.05 \\
9.67 \\
10.65 \\
11.68 \\
11.42 \\
12.98 \\
14.67 \\
6.15 \\
5.89 \\
60.06 \\
48.51 \\
146.15 \\
152.78 \\
151.81 \\
143.55 \\
55.78 \\
64.81 \\
38.92 \\
21.50 \\
66.91\end{array}$ & $\begin{array}{rr}3 & 24 \\
4 & 45 \\
4 & 44 \\
4 & 02 \\
3 & 82 \\
3 & 81 \\
3 & 76 \\
3 & 56 \\
3 & 54 \\
3 & 52 \\
3 & 21 \\
3 & 20 \\
2 & 95 \\
2 & 93 \\
2 & 86 \\
2 & 80 \\
3 & 65 \\
6 & 15 \\
2 & 63 \\
3 & 13 \\
15 & 77 \\
6 & 06 \\
10 & 67 \\
11 & 41 \\
11 & 42 \\
11 & 82 \\
23 & 46 \\
24 & 48 \\
22 & 61 \\
25 & 01 \\
11 & 05 \\
\end{array}$ & \begin{tabular}{cc|}
$\$ 3$ & 25 \\
2 & 79 \\
3 & 25 \\
- & 5 \\
3 & 25 \\
3 & 50 \\
3 & 50 \\
- \\
- \\
3 & 25 \\
3 & 25 \\
- \\
3 \\
3 & 25 \\
3 & 25 \\
3 & 00 \\
3 & 00 \\
- & - \\
1 & $7 \%$ \\
1 & 77 \\
20 & 00 \\
12 & 50 \\
25 & 00 \\
30 & 00 \\
25 & 00 \\
25 & 00 \\
15 & 00 \\
15 & 00 \\
12 & 00 \\
10 & 00 \\
- \\
\end{tabular} & $\begin{array}{l}-a \\
-b \\
-a \\
- \\
-a \\
-c \\
-c \\
- \\
- \\
-a \\
-a \\
- \\
- \\
+a \\
+a \\
+d \\
+d \\
-\end{array}$ \\
\hline
\end{tabular}

Note.- $u$, at rate of $a$ cents per quart: $b, b$ cents per quart; $c, 8$ cents per quart; $a, b \%$ cents per
uart; $e, 4$ cents per quart. 
Table Illustrating the Differences in Dairy Products, and Comparing the Latter with various other Standard Food Products.

\begin{tabular}{|c|c|c|c|c|c|}
\hline $\begin{array}{c}\text { StaNdard ARTicles of } \\
\text { HuMAN Food. }\end{array}$ & $\begin{array}{l}\text { Pounds } \\
\text { Protein } \\
\text { in } 100 \\
\text { pounds. }\end{array}$ & $\begin{array}{l}\text { Pounds } \\
\text { Carbo- } \\
\text { hydrates } \\
\text { in } 100 \\
\text { pounds. }\end{array}$ & $\begin{array}{c}\text { Computed } \\
\text { Value per } \\
100 \text { pounds. }\end{array}$ & $\begin{array}{c}\text { Average } \\
\text { Market } \\
\text { Price per } \\
100 \text { pounds. }\end{array}$ & $\begin{array}{l}\text { Price, } \\
\text { Greater } \\
\text { or Less } \\
\text { than } \\
\text { Value. }\end{array}$ \\
\hline Beef, without bone, average.. & 21.39 & 9.08 & $\$ 1632$ & $\$ 1632$ & 一 \\
\hline 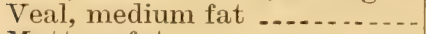 & 18.88 & 13.89 & 1457 & 1500 & + \\
\hline Mutton, fat $\ldots \ldots$ & 14.80 & 63.73 & 1512 & 1500 & - \\
\hline Pork, fat . & 14.54 & 65.35 & 1504 & 1300 & - \\
\hline Fowl, domestic . . . . . . . . . & 18.49 & 17.54 & 1454 & 1600 & + \\
\hline 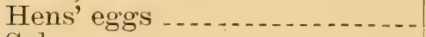 & 12.55 & 21.74 & 1056 & 1065 & $+f$ \\
\hline Salmon & 13.10 & 12.67 & 1032 & 3000 & + \\
\hline 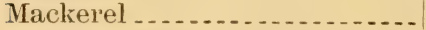 & 23.42 & 11.83 & 1769 & 1000 & - \\
\hline Codfish, dried _............. & 17.90 & 2.25 & 1305 & 800 & - \\
\hline Oyster's & 4.95 & 3.27 & 397 & 1000 & + \\
\hline 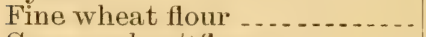 & 8.91 & 76.12 & 394 & 300 & - \\
\hline Coarse wheat flour . . . . . . . & 11.27 & 75.79 & 416 & 250 & - \\
\hline Oat meal $\ldots \ldots \ldots$ & 15.50 & 74.37 & 452 & 300 & - \\
\hline Corn meal & 12.17 & 78.02 & 455 & 150 & - \\
\hline Fine wheat bread ............. & 6.82 & 53.69 & 283 & 400 & + \\
\hline Coarse wheat bread ......... & 6.23 & 51.32 & 267 & 300 & \\
\hline Potatoes $\ldots$ & 1.79 & 20.84 & 101 & 100 & $\underline{1}$ \\
\hline Rice & 1.81 & 76.61 & 324 & 600 & + \\
\hline Beans . . & 23.56 & 52.10 & 444 & 400 & 1 \\
\hline 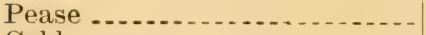 & 22.63 & 56.25 & 451 & 500 & + \\
\hline Cabbage. . & 2.95 & 9.24 & 066 & 100 & \\
\hline Onions $\ldots$ & 1.68 & 10.99 & 061 & 200 & \\
\hline Tomatoes _........ & 1.25 & 4.66 & 031 & 200 & \\
\hline Sugar, from cane......... & 0.35 & 96.73 & 390 & 600 & \\
\hline Honey ........ & 1.29 & 81.43 & 339 & 2500 & \\
\hline Apples ........ & 0.39 & 13.74 & 059 & 150 & \\
\hline Dried apples .. & 1.06 & 55.97 & 235 & - & \\
\hline Peaches ....... & 0.65 & 12.57 & 057 & - & \\
\hline Strawberries .. & 1.07 & 8.48 & 045 & - & \\
\hline Grapes _. & 0.59 & 17.11 & 074 & - & \\
\hline Banana, yellow, hard........ & 1.41 & 30.85 & 123 & - & \\
\hline Banana, fully ripe.......... & 4.82 & 20.96 & 132 & - & 十 \\
\hline
\end{tabular}

Note. $-f, 16$ cents per dozen.

Certain general explanations and remarks should be made in regard to these tables before referring to any special points of interest. In each table the first column gives the name of the article of food to which the figures on the same line apply. The remaining columns in the two tables are duplicates in their headings and objects. 'The column headed "Protein" gives in pounds and hundredths of a pound the average quantity found in one hundred pounds of the article named. By "protein" is meant that class of compounds, the most important of all the ingredients of food, whose four elements are carbon, oxygen, hydrogen, and especially nitrogen (with, perhaps, a little sulphur or phosphorus). Under the head of protein are, therefore, included what are variously called albuminoids, gela- 
tinoids, nitrogenous parts, and proteids; the most familiar example of which is the albumen, or "white" of eggs. The next column, headed "Carbo-hydrates," gives likewise the quantity of this class of nutrients in one hundred pounds, expressed in pounds and decimals. These substances include sugar, starch, dextrin, digestible woody fibre, etc., which, as well as fats, are composed of the three elements, carbon, oxygen and hydrogen. It should be especially noted that in these tables, to sare a column and simplify their appearance, special columns for fat hare been omitted, and the fat have been included in the columns of carbo-hydrates, being first reduced to an equivalent on the ratio previously stated. This accounts for the apparent anomaly of the figures in this column, in some cases -butter, for example-indicating more than one hundred pounds of carbo-hydrates in a hundred pounds of the article named (!). The explanation is as given-that the fat, having the higher nutritive value, has been multiplied by $1 . i 5$ before adding to the carbo-hy. drates proper. The reason undoubtedly was, that the nutritive parts of food are commonly, if not correctly, classed as flesh-forming and heat-producing, or life-sustaining. Fats and carbo-hydrates both belong to the latter class, and hence are expressed in combination. In these tables, therefore, the protein columns represent fleshforming parts of the food, and the carbo-hydrates columns, heat. producing. (It is a recognized fact that this last classification is defective in several particulars, but especially because the protein o food may be changed in the body into fats and carbo-hydrates, and serve, as do the latter, for fuel in sustaining animal heat and life. These two columns are based upon fixed facts, determined by chemi cal research, and not liable to change, although slight modification may result from adding new analyses, and the articles may, in the course of time, while maintaining the sime name, acquire new char acteristics. The next column, headed "Value," is based upon thos before, with the rates assigned for protein and carbo-hydrates. pe pound. in animal and regetalble suhstances, and thus gives the actual value of the nutrients in one hundred pounds each of the foods named computed upon their chemical composition. If exceptions are take to the assumed prices of the basic articles, it is manifest that by simple calculation, based upon existing market rates, the column of food values may be easily reconstructed to suit any given locality As the figures stand, however, they are relatively correct, and serv our purpose better, in comparing different foods, than do those o the previous columns. The columns headed "Average Marke Price" are simply for illustration, and will vary more or less wit 
time and place. The purpose of the signs in the right hand columns have already been explained.

It may be noticed that the tables do not include the mineral constituents of food, which are usually denominated the ash. No diet is complete without some mineral ingredients, and in milk for babes these are an important factor. But sooner or later after we begin to crawl-and sooner rather than later-we all, it is said, "eat our peck of dirt," so that this omission may be regarded as unimportant, and, perhaps, be thus accounted for.

For the single object of showing the differences in dairy products, and hence, for this occasion, we should have found it more satisfactory to place the fats in a separate column, and also have a column of total solids. But I thought it best to use the tables as originally published, rather than change any figures.

At this point, attention is especially invited to the demonstration given by these tables of the cheapness, when compared with their nutritive value, of nearly all dairy products (butter excepted). Skim milk, buttermilk and cheese, at their usual retail prices, are cheaper, as nutritious food, than any other article on the list, and are approached in this respect only by fresh mackerel and dried codfish. Butter is an exception, and, while it unquestionably serves special purposes in the human diet, it must, upon the basis of its chemical composition, be regarded as a delicacy or luxury, and not as a food. It ordinarily costs two or three times its real food value, and often more. Of the more solid foods not specially perishable, nothing begins to compare, in cheapness, with cheese. What shall be said of the domestic economy of America, where more butter and less cheese are consumed, per capita, than in any other nation in our zone? And what of the wisdom of the lawmakers, in some of our States and great cities, who, to escape the difficulties of regulating the milk traffic, utterly ignore the vital question of cheap and wholesome food for the poor, and, sanctioned even by boards of health, absolutely prohibit the sale of skimmed milk, and actually authorize the destruction of all that can be found!

Now, let the consideration be confined to that part of the first table which relates to milk. Great differences are here shown in the composition, and hence the value of the average milk of cows of different breeds. It is worthy of notice that the milks which, as shown in the column for carbo-hydrates, have the most fat, are, as a rule, also the richest in protein, or curd. This table indicates at once the breeds of cattle whose milk we should buy, if consumers, and which we should keep, to be the producers of milk of high quality. 'The milk 
of the chemists" standard, "average cow's milk" (as determined by very many analyses), and of all the breeds enumerated, except four, usually sells for less than its computerl value. Four breels, all of the same general class of stock, yield milk so low in its nutrients that it is, on the average, not worth the prices at which it usually sells. 'This difference in value would be still more marked, if the same selling price was assigned to all milk, but special allowance is made in the table for higher prices for milk of exceptional richness, and low prices for that of poorest quality.

Manifestly, we do not buy milk, and we are foolish if we produce it, for the water it contains. The greater the proportion of water, the poorer, less valuable the milk. It is the solid portion, and that only, which gives milk its food value, and I firmly believe the time is near at hand when its commercial value will be fixed by the total solids. Indeed, a system of grading milk according to its solids, and selling it at different prices, fixed by its quality, has already been inaugurated by at least one enterprising milk dealer in Philadelphia. To illustrate : compare the milk of one of the breeds of high quality, and one of those of a low standard, with the general average. We will take the fourth from the top, the Jersey, and the fourth from the bottom, the Holstein, as being familiar breeds, and expand the figures of the table, to give the full average analyses:

\begin{tabular}{c|c|c|c|c|c|c|c}
\hline Krnd of Mrrk. & Water. & Solids. & Casein. & Fat. & Sugar. & Ash. & $\begin{array}{c}\text { Value } \\
\text { per cwt. }\end{array}$ \\
\hline Maximum, Jersey _..... & 85.18 & 14.82 & 3.98 & 5.06 & 5.03 & .75 & $\$ 382$ \\
Mean, Average of all_... & 87.31 & 12.69 & 3.41 & 3.66 & 4.92 & .70 & 324 \\
Minimum, Holstein_..... & 87.92 & 12.08 & 3.15 & 3.30 & 4.90 & .73 & 295 \\
\hline
\end{tabular}

A graphic illustration is more satisfactory than the mere figures. Three sets of glass jars, six in each, can be prepared so as to show respectively the component parts of one gallon of each of the three grades of milk represented by the figures in the table just above, and thus strikingly exhibit the difference in composition of these represertative samples of milk.

The question may be asked: Is not this theoretical? Iot at all! Excepting the single item of the relative nutritive value of fats and carbo-hydrates, everything about these tables is fact, - simply the condensed record on innumerable facts, determined by many careful men, working through a long term of rears. 
Is this not all scientific work? Yes, it is, mainly, the work of scientific men. But if the word "science," which to some is so repugnant, is, as it ought to be, interpreted as meaning simply the truth, or, as Davy so well defined it, as "common sense, refined and classified," there seems no reason why these records should not be accepted by the most "practical" man. While I have the most profound regard for science and scientific methods, I measure the value of both solely by their practical results. And I believe that the statements thus far made herein, accord perfectly with practical experience. They are fully substantiated by the facts developed in the dairy farming of this country, at the present time, and by its allied industry and commerce.

So far recorded facts. But now, when we come to a discussion of the lessons they teach, and seek for examples in practice, we necessarily reopen "the battle of breeds." Only facts which can easily be authenticated will be given, and comparisons will be fairly made, but it will be impossible to occupy strictly neutral ground. The question is, Which cattle produce the best milk, - the best to sell, and the best to buy? I will not attempt to further argue that the best milk is the most profitable, for seller as well as for buyer. We will take the most familiar rival dairy breeds, - the IlolsteinFriesians (as now called) and the Jerseys. According to the chemists, the average milk of Holstein cows has but 12.05 per cent. of solids, including 3.30 per cent. of fat. 'This would barely escape the lowest legal standards that are justifiable. It will readily be understood that the mrobability is, that more of the milk of cows of known breeding has been from animals above the average quality, rather than below. Do practical results sustain the testimony of chemistry? Within two years, I have personally known of two herds of highly bred Holstein-Friesian cattle, many of them imported, and valued as better than the average of their breed, owned in two different States, by men of absolute integrity, and yet both these owners have suffered the penalty of the law, because the milk sold from their herds, and which they insisted was pure milk from their fine cows, fell below the local standard in their respective States. 'The case of Uriah Borten, of Rancocas, N. J., the facts of which have been given to the public, is another of a similar nature. I know of the case of a substantial dairy farmer, who made his whole living from his farm, and who sold off a profitable dairy herd of mixed blood, and replaced them with Holsteins, in which he invested all his savings. He did well in the sales of cattle, became a large importer, and one of the most highly esteemed 
expert judges of the "blacks and whites" in his section of the country. Lately he surprised his neighbors by selling out his purebred cattle, stocking his farm with grade Jerseys, and resuming his old dairy business. Upon being asked to explain, he stated that he was unwilling to continue selling to other people, as fine dairy stock, animals which in his own practice had proved to be unprofitable; that he had lost, by keeping IIolsteins as his dairy herd, about as much as he had made trading in them, and resolved to return to stock that could be kept at a profit. Another case, with the details of which I am familiar, is this: A man, whose name you would all recognize, owns a large farm near one of our principal cities, well adapted for milk production. He had a stock of Jerseys and grade Jerseys, and mixed-blools, or " natives," and bought a good milk route, on which he disposed of their products. 'The demand soon exceeded his supply, and upon the advice of friends, he purchased Holstein-Friesians to increase his herd. Fancying the fine, large animals newly acquired, and having ample means, he sold off all but three or four of his Jersey cows, and, with this exception, stocked up entirely with Holsteins, buying at high prices from several of the most celehrated breeders in America. Almost immediately his milk route began to rum down, and he had nearly lost his whole trade before he became sittisfied of his mistake, and began to sell Holsteins and buy Jerseys. Now I see his name, every few weeks, as the buyer of registered Jerseys, from the most noted deep-milking families. I was lately told by the farmer of this gentleman, that the latter had become fully convinced as to which breed of cows gave the best milk, and were the ones best adapted to a profitahle milkselling business. Our table gives, for average Holstein milk, total solids, 12.08, and fats, 3.30. Not long ago I saw the record of the analyses of twelve samples of milk, from five exceptionally fine Holstein cows-none better anywhere-and one or more being at the time of examination specially fed to produce rich milk for a butter trial. The work was done by an eminent chemist, and the average result was, total solids, 10.93, and fats, 2.84. Analyses of the milk of a herd of Holsteins near Philadelphia, given by the owners, in 1sst, averaged for total solids, for April, 11.33 : May, 11.59 : .June, 11.64 -all on liberal rations of substantial and good milk producing food. At the State Experiment Station in Wisconsin, examinations of IIolstein milk gave total solids, 11.2S, and fat, 2.8s. For three consecutrve years, at the Royal Dairy Show in London, the milk of the Holsteins exhibited has been tested and found to average, total solids, 11.80, and of this $2.9 \%$ per cent. was fat. Such milk cannot be sold, under 
the laws of the State of New York, outside the county in which it is produced.

Let us see if milk of a better quality cannot be found. The chemists' average for Jersey milk, according to our table, is for total solids, 14.82, and for fats, 5.06. As before remarked, this may be a little high, and for the reasons stated. But I have in my possession the record of more than a year, of weekly tests made of the milk sent to Philadelphia daily, for sale, from a herd of registered Jersey cows, owned by Mr. H. Lippincott, of Cinnaminson, N. J. The dealer who receives this milk, on some day in every week, according to his fancy, samples the milk and has the total solids chemically determined. "The record for the herd for a year just closed, shows a range from 13.13 one week in June, to 16.16 in January, and an average for the year of 14.76 per cent. total solids. This comes pretty well up to our standard (only 6 -100ths of 1 per cent. short), and the record would undoubtedly have been higher but for the fact that a full half of the herd were heifers with their first calves. In passing, it may be well to notice that this record shows what always proves true, that the lowest per cent. of solids in a year is at the flush of June pasturage and during the heat and flies of July and August, and the best milk is from good Winter feed. Mr. Lippincott's monthly averages were as follows: June, 14.10 ; July, 13.83 ; August, 14.03; December, 15.21; January, 15.46 ; February, 15.19. There is a still better record for a whole year. 'The dealer who handles Mr. Lippincott's milk also has the product of Mr. John P. Hutchinson's herd of registered Jerseys, at Georgetown, N. J., and has made similar tests of that milk. Although the details are not given, this dealer, Mr. George Abbott, $\mathrm{Jr}$, of Philadelphia, informs me by letter that for the entire year of 1886, the milk from Mr. Hutchinson's herd averaged 15.45 per cent. solids. 'This is more than one-half per cent. above the standard of the table. He adds, as further examples, the following averages of solids, for the year 1886, in the milk of certain herds handled by him, and says, "These are first class representutive herds of the breeds named, and the averages are for the entire year": Registered Jerseys, 14.3i, 14.49, 14.\% 14.80 , and 14.93 ; registered Guernseys, 14.61, 14.68, and 15.14 per cent. 'The average of the ten herds examined by $\mathrm{Mr}$. Abbott is 14.80 , which is a practical endorsement of the table, or the average as fixed by science.

During a long period of close observation at the New York Agricultural Experiment Station, where the milk from several unregistered Jersey cows was tested daily, the total solids averaged 14.45, ranging from 13. 10 to 15.90 . During the trial a great variety of food was used, 
sometimes being intentionally poor. Unfortunately, the percentage of fat, as distinct from the other solids, was not taken; but one may always be certain that where the total solids run above $13 \frac{1}{2}$ per cent. the milk is rich in fats, for instances of "solids not fat," above 10 per cent., are very rare. While at Houghton Farm, I had the milk of Jursey cows not regularly but repeatedly examined. The solids ranged from 13.62 to 15.96 per cent. and the fat was never found below 4.30 in the milk of the herd, while it sometimes reached 6.61 per cent. and averaged 4.93 per cent. So much for the quality of the average milk of good business herds of dairy cows.

The impression prevails in some places, that while the milk of Jerseys is of high quality, it is always in small quantity per cow. This is rather outside the bounds of my present subject, but I will venture to briefly notice this point. 'The criticism is not sustained by the facts. The habit of an even and long continued flow of milk, which is one of the most valuable characteristics of this breed, and of great importance to the producer of milk for sale, results in much larger annual records of milk product in good dairy herds of Jerseys than they are generally credited with. One year while I was at Ifoughton Fam a herd of fifteen, including two aged cows and three undeveloped heifers, produced an arerage of 5,844 pounds 3 ounces, or $2,718 \frac{1}{4}$ quarts per head. It is very well known that dairy herds, kept for the quantity of milk produced, but with little regard to quality, and maintained by frequent culling and purchases of fresh cows, are considered as doing well to a verage 2,800 quarts per cow, or 6,000 pounds. Herds capable of an anmual yield of 3,500 quarts, or $\%, 500$ pounds a year, to every cow fed for the year, and which in quality reaches the New York standard, are exceedingly rare. Yet Jersey herds, maintained by their own increase, are by no means uncommon, which average over 6,000 pounds of milk a year, and that of the highest quality. Mr. A. B. Smith, of Eagle, Mich., in the year 1855, had a herd of six pure Jersey oows and three high-grade Jerseys, which averaged $\%, 100$ pounds of milk each. The large herd of registered Jerseys at Deerfoot Farm, Massachusetts, where the daily record of every cow has been kept for fifteen years, shows a total average of about 1,500 quarts or 5,400 pounds per head for this long period. Single cows in this herd averaged 2,93:), 2.941, and $3,3 \% 1$ quarts a year, for seven successive years, being from 6,200 to 7,250 pounds. The Echo Farm at Litchfield, Conn., have published a list of the names and numbers of a dozen of their registered Jerseys, sereral of them ten or twelve years old, 
with their yearly milk yield, which averages for the lot 8,385 pounds or 3,900 quarts. Messrs. Miller \& Sibley of Franklin, Penn., have taken pains to purchase and to breed Jersey cows of large milking habits, and, as showing their success, they publish the records of twelve cows which averaged for a year 8, \%00 pounds or over 4,000 quarts of milk each. One heifer with first calf gave 10,101 pounds in twelve months, before three years old; another young cow gave 10,329 pounds on ordinary feed; and an older one, 16,153 pounds, or an average of 20 quarts a day for the whole year. That this last yield was milk of good quality is sufficiently proven by its making over 927 pounds of butter, or a pound of butter to every 8 quarts of milk. 'These facts show that there is no trouble in getting Jersey cows whose product is large in quantity as well as high in quality.

A letter recently received by me from Mr. Edward Austen, of Filston Farm, Glencoe, Md., is appropriate in this place. I requested this gentleman to send me the annual yield of his cows, and what he knew of its quality. Mr. Austen is a man of accurate, systematic habits, who, after some years in business life, now owns and manages in porson a dairy farm in Maryland, producing milk for sale in the city of Baltimore. He once said to me that he found the only safe milk business was making the best milk, and he would not keep a cow in his herd that did not prove profitable as a dairy animal. But his letter tells the story : "Twenty cows in my herd of A. J. C. C. Jerseys, being all the cows I had that had dropped more than one calf, yielded 119,495 pounds 14 ounces of milk in twalve months, being an average of $5,9 \approx 4 \frac{3}{4}$ pounds for each cow, and every one of these cows bore a calf during the year. 'The milk of every cow was weighed separately, morning and night, every day except Sunday, when the yield was assumed to be the same as that of the previous day. Calves were allowed to suck their dams for three days and no estimate made of the milk so used. Eight of these cows were imported and the others home-bred. The lowest record for the year was that of an imported cow, over twelve years old, 4,181 pounds 6 ounces; and the highest was a home-bred cow, 8,383 pounds. I have only made two butter tests for seven days, among these cows. One gave 16 pounds 12 ounces, and the other over 14 pounds of butter, both on a trifle more than the regular dairy rations. I made quite a number of tests of one to three days, on the regular feed, and was quite satisfied that there was only one cow in the twenty that would not make over 10 pounds of butter per week on their rag- 
ular daily food, and that a majority of them would go over 11 pounds. I have no other means of ascertaining the quality of the milk produced except the cream glass, which, used daily, showed from 19 to 31 per cent. of cream,-whatever that may prove. If we had an Agricultural Experiment Station in this State, I would know the per cent. of fat and total solids. I have always, since my boyhood, been a lover of cows, and began with Devons, - then tried Ayrshires, and finally Jerseys. For all dairy purposes I shall stand by the latter. 'The Guernseys stand high in my estimation, but I lave reason to think that they are not such persistent milkers as the Jerseys. You did not ask my opinion of Jersey cows, or the respective merits of the various breeds, but I throw this in."

Good cheese is made from whole milk, or that from which no part of the cream has been taken. In old times little else was thought of. Now so many inferior kinds are made that the designation "full cream cheese" is given to the standard product of first quality. The differences in this class of dairy products, to which I shall briefly refer, are not those incident to the processes which result in "skims" and "filled" cheese (lard or oil substituted for fat removed in cream) but relate to the variations occurring in the quantity and quality of full cream cheese made from an equal weight of whole milk from different breeds of cows.

One would not at first think that milk of extreme richness of fat or cream, and specially adapted to butter making, would be desirable for cheese. But in well made cheese, a very large share of the total solids of the milk are secured in the product, nearly all the caseine and the fat, although most of the sugar escapes in the whey. Consequently, that which is richest in total solids will make the most cheese per hundredweight of miik; and the general statement is true, that milk best suited to butter is most profitable for cheese. The data regarding cheese made from the milk of pure bred cows of different breeds is meager, but the principle stated is borne out by experience with .Tersey milk. The general average in good cheese making districts is ten pounds of cheese to every hundredweight of milk; with milk from pure Jerseys, in large number, on the common factory plan, it has been found that the same weight of milk will give over twelve pounds of cheese, a gain of more than 25 pe: cent. in quantity of product. At several public exhibitions in Canada during recent years, and also at the Ontario Experiment Farm, the milk from selected cows of different breeds has heen tested in rarious ways, and among the rest with reference to the available curd or 
cheese making qualities. (The animals being few in number, I do not regard these results as alone settling any points of comparison, but they may serve in corroboration of other statements made.) The details have been widely published, so it is sufficient, for present purposes, to state the general results. The order of merit as cheesemakers indicated was as follows: 1st trial, Jerseys, Shorthorns, Ayrshires, Guernseys, Devons, Galloways, Holsteins, Polled Aberdeens; 2d trial, Jerseys, Ayrshires, Shorthorns, Holsteins ; 3d trial, Jerseys, Ayrshires, Devons. In the second trial, the Ayrshires led on quantity of curd without fat, but with curd and fat took second place. With this exception, the Jerseys stood first in quantity of curd as well as of fat. In regard to quantity of caseine alone, in the milk of different breeds, the table previously referred to shows their relation with approximate accuracy, in the column headed "Protein."

The same table gires the differences in chemical composition and computed value, between average full-cream cheese, the same made from pure Jersey milk, half skim cheese, and that made from skimmilk and from whey. There is very little light here as to the merits of different breeds of cattle, as respects the quality of cheese made from their milk, although the surprising fact is shown that Jersey made cheese is so much richer in both caseine (proteids) and fat, that it is worth a cent more a pound than the average full cream cheose of America, as an article of nutritious food. Upon this point, Prof. Arnold says in his American Dairying: "The business of the Jersey cow is emphatically that of butter making. Her milk, however, is rich in cream matter, and, contrary to the general belief, is capable of making as fine cheese as it does butter. It is a new feature, worthy of note in the uses of this breed of cattle, that their milk can, without the waste of its buttery matter, be converted into a strictly fancy cheese, as rich as English Stilton. Analyses of cheese from pure Jersey milk, made at Cornell University, have shown over 40 per cent. fat.

The table upon which we have been depending gives so little in regard to differences in cheese, that I append another, with considerably more data in this cornection: 
Table of Analyses of Different Kinds of Cheese.

Description of Cheese-100 Pounds.

1. Average of 83 samples Full-cream Cheese ......... . . . . . . . . .

2. Average of 21 do., N. Y. State Dairy Commissioner's Report....

3. Full-cream, premium at N. Y. State Fair. (Flint's Dairy Farming; of pure Jersey milk) _..........

4. Full-cream, premium at N. Y. State Fair .........................

5. Full-cream, premium at N. Y. State Fair ........................

6. Full-cream, premium at N. Y. State Fair ..............................

7. Full-cream, premium at N. Y. State Fair _....................

8. English average, by Sir Lyon Playfair

9. English Cheddar, two years old, Prof. Johnston _...............

10. English Double Gloucester, one year old, Prof. Johnston..............

11. English North Wilts, one year old, Prof. Johnston ................

12. Half-skim, average of 8 English samples $\ldots$. State ................

13. Half-skim, N. Y. State of 9 English

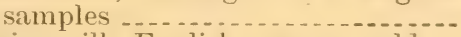

15. Skim-milk, English, one year old_..-

16. Whey Cheese, average 6 samples..-

\begin{tabular}{|c|c|c|c|}
\hline $\begin{array}{c}\text { Water. } \\
\text { lbs. }\end{array}$ & $\begin{array}{l}\text { Fat. } \\
\text { lbs. }\end{array}$ & $\begin{array}{l}\text { Protein or } \\
\text { Curd, } \\
\text { lbs. }\end{array}$ & $\begin{array}{l}\text { Ash. } \\
\text { lbs. }\end{array}$ \\
\hline 35.75 & 30.43 & 27.16 & 4.13 \\
\hline 27.82 & 28.61 & 38.10 & 4.39 \\
\hline 38.46 & 31.86 & 25.87 & 8.81 \\
\hline 28.37 & 31.28 & 30.52 & 3.83 \\
\hline 28.62 & 29.90 & 37.66 & 3.82 \\
\hline 33.75 & 28.95 & 33.70 & 3.60 \\
\hline 28.11 & 41.03 & 28.18 & 2.68 \\
\hline 38.78 & 25.30 & 31.02 & 4.90 \\
\hline 36.04 & 30.40 & 28.98 & 4.58 \\
\hline 35.81 & 21.97 & 37.96 & 4.25 \\
\hline 36.34 & 28.09 & 31.12 & 4.41 \\
\hline $\begin{array}{l}46.82 \\
38.25\end{array}$ & $\begin{array}{l}20.54 \\
19.93\end{array}$ & $\begin{array}{l}27.62 \\
38.48\end{array}$ & $\begin{array}{l}3.05 \\
3.24\end{array}$ \\
\hline $\begin{array}{l}48.02 \\
43.82 \\
23.57\end{array}$ & $\begin{array}{r}8.41 \\
5.98 \\
16.26\end{array}$ & $\begin{array}{r}32.65 \\
45.04 \\
8.88\end{array}$ & $\begin{array}{l}4.12 \\
5.18 \\
4.76\end{array}$ \\
\hline
\end{tabular}

One product of the dairy only remains to be considered. This is butter,-the culmination of the dairyman's art. This great delicacy consists of the natural fat of the milk, with some water. and should contain nothing else, except as we choose to flavor it with salt. The perfection of butter making is to secure these fats, separated from the serum or fluid of the milk, and gathered in a mass, with as little chemical and physical change as possible. So it may be said that we get the butter from the milk, rather than “ make" it. Cnfortunately, perfection has not been reached in this art, and there is always present in butter, mingled with the fats and mainly dissolved in the water, more or less of the protein or curd and of the sugar of milk. It is these constituents which play the mischief with butter, by starting the chemical changes leading to rancidity and decomposition, and which we consequently endeavor to reduce to the minimum. 
While, therefore, in nearly all other food products, the presence of protein (because of its high nutrient quality) adds to the value of the article,-if we place butter at all in the list of foods, that which has the highest nutrient value is the poorest in those qualities which go to make fine butter. We buy butter for its fat, and the more fat and the less water and protein, the better it is, as butter. In our table comparing foods, there are averages given of butter of different kinds, and, for the reasons stated, the best butter is designated by the highest figures in the column of carbo-hydrates, and not in the "Value" column.

Examining butter in.detail, it is found to be composed of very complex fats, the chemist naming eight or ten, which number he divides about equally into insoluble fatty acids and volatile fatty acids; also, in their combination with glycerine, into solid fats and fluid fats. It is not my purpose, however, to go into these details, but to call attention to the differences in butter, as it usually exists. Among the many writings upon the composition of butter none has seemed to me so ingenious and painstaking in method, or practical in conclusion, as the work of Dr. S. MI. Babcock, chemist of the New York Agricultural Experiment Station at Geneva. At the annual fat stock and dairy shows in Chicago, in 1885 and 1886, and at the Bay State Agricultural Society's fair at Boston, in October, 1856, I was able to secure for this gentleman samples of the premium butters of known origin, - the certificate of the maker, as to the method and breed of the cows giving the milk, accompanying every exhibit. Upon these Dr. Babcock pursued his investigations, and he personally obtained another set of samples of butter, with the history of each, at the New York Dairy and Cattle Show, May, 188;. Based upon his examinations of this last lot, Dr. Babcock prepared his report upon "Variations in the Composition of American Butters," which I have already mentioned, and to some parts of which I now wish to refer. The butters upon which he worked, and which gave the results presented in his tables (see Proceedings of Society for the Promotion of Agricultural Science, eighth meeting, New York City, August, 188\%, page 1\%), were twenty-six in number, seven being from Jersey cows, seven from pure Holstein-Friesians, two from pure Guernseys, one from Ayrshire, and nine of premium butter from mixed milk, no special breed predominating.

These samples were examined to determine the variation liable to occur in the best grades of American butters, and especially to note how far these variations might be attributed to breed and to the individuality of the cow. (Some of the samples representing each 
breed were from the milk of a single registered cow.) The general determinations were noted as a matter of some interest, but attention was mainly devoted to the composition of the butter fats. 'The following are the average extreme figures for these prize butters, and probably fairly represent the average composition of first-class butter in this country:

\begin{tabular}{l|r|r|r|r}
\hline & Water. & Fat. & Ash. & Curd. \\
\hline Highest & & & & \\
\hline Average & & & & \\
\hline
\end{tabular}

It may be noted that these butters averaged better than those in the food table, the average here being about equal to the Ayrshire butter in that table, and the poorest here being rather better than the poorest there. (It should also be stated that none of the milk and butter of these and other recent examinations by Dr. Babcock are included in the averages of the food tables previously noticed.)

The further examinations comprised determinations of the relative quantity of volatile fatty acids; of insoluble acids, by what is called the "Iodine Number" ; of the melting point; and a test devised by Dr. Babcock of the viscosity of soap solutions made from butter. The technology of the chemical processes it is hardly desirable to describe here, but they are necessarily referred to by their peculiar names in the following abstract from Dr. Babcock's table and his deductions from it:

Comparisons of Butters from Different Breeds of Cows.

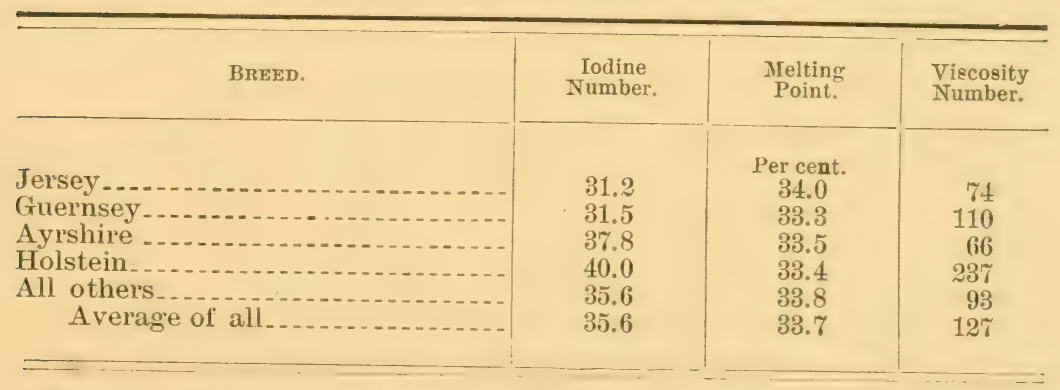

The volatile fatty acids are not included in the table, because it was found that while the individual variations within all the breeds 
was very great, the influence of breed did not appear in this particular.

The insoluble fatty acids were found quite constant in amount, but very variable in composition. "The "Iodine Number" indicates the relative proportion of oleic acid and the absolute quantity of this soft fat in the total fats of the butter. "The influence of breed upon this factor is very great; one of the most marked characteristics of Holstein butter, when compared with that of the Jersey or other breeds, being shown in its high per cent. of olein. This renders butter less firm in warm weather, although it does not materially lower the true melting point." (The quotations are from Dr. Babcock's article. Ile preferred to compare Holstein and Jersey butter because they showed the greatest contrast, and also because, having several samples of each, equal in number, the averages were deemed more reliable than those of the other breed of which he had only one or two samples.)

The melting point is expressed in degrees of the Centigrade thermometer, and the record illustrates the observed fact that it requires a higher degree of temperature to melt Jersey butter than the average.

From a test not shown by the above abstract from his table, Dr. Babcock determined "that the proportion of palmitic and other fatty acids of less molecular weight than oleic and stearic, is considerably greater in Jersey than in Holstein butter."

The viscosity test indicated breed peculiarities very clearly, as well, in the composition of butter from single cows not shown by other methods. This is a very clever method of testing, and especially applicable to the detection of adulterants in butter; it is fully explained in the Report of the N. Y. Agricultural Experiment Station for 1886. In this instance, the pure Holstein butters had an average viscosity of $23 \%$, ranging from 112 to 461 ; the pure Jersey butters averaged $\%$, and ranged from 50 to 103 . 'These numbers are relative only, but representative of a marked contrast. Dr. Babcock says, "The other conclusions in regard to the differences which exist between Jersey and Holstein butters are confirmed by the viscosities of their soap solutions," (i. e., by his viscosity test).

Although these fine analytical tests may not be well understood by these brief technical references, it seemed proper to adhere closely to the conclusions of the original report, before stating the practical deductions. Now, as to the latter: "The influence of breed of the cow upon the composition of the butter fat is no less marked than it 
is upon the composition of the milk, and, contrary to general acceptation (this statement is based upon other investigations), that does not appear to be materially affected by the character of the food." (Dr. Babcock.) Among the effects of breed thus noted, are those differences in butter which relate to its firmness, resistance to heat, texture or "grain," flavor and general high quality, by reason of a larger proportion of the more delicate fats. In all these particulars, butter from pure Jersey milk excels, while that from other breeds follows in the order given in the last table.

In conclusion, it is hoped that facts of a reliable character have been herein presented in sufficient number and with such reasonable distinctness as to show the great differences which occur in dairy products, - milk, cheese and butter, - the influence of breeds of cattle in causing these differences, and the consequent practical value of a study of this subject when selecting stock for the profitable conduct of any branch of dairying. 



\section{LIBRARY OF CONGRESS}

|| || || || || || ||| ||||||||||||||||||||||||| 00028549271 